\title{
Growth and longevity of jack-knife shrimp, Haliporoides sibogae, off Nagasaki, Japan
}

\author{
Kentaro Homma ${ }^{1} \&$ Jun Hashimoto $^{2}$ \\ ${ }^{1}$ Graduate School of Science and Technology, Nagasaki University, 1-14 Bunkyo, Nagasaki 852-8521, Japan \\ ${ }^{2}$ Faculty of Fisheries, Nagasaki University, Nagasaki University, 1-14 Bunkyo, Nagasaki 852-8521, Japan
}

Received 25 October 2011; Accepted 18 April 2012

\begin{abstract}
The jack-knife shrimp, Haliporoides sibogae, is an unutilized fisheries resources with a population widely distributed on the continental slope in the East China Sea, southwest of Nagasaki. The growth and longevity of this shrimp were investigated based on 3,733 specimens collected by monthly beam-trawl sampling between May 2006 and March 2009. The spawning season of the H. sibogae population southwest of Nagasaki was from November to March, and the main spawning season was in January and February. The longevity of H. sibogae was estimated to be about 38 months and the growth coefficient of this shrimp population was found to be less than half that of another two populations in Japanese waters. The secondary sexual characters of $H$. sibogae females were also confirmed.
\end{abstract}

Key words: East China Sea, growth, Haliporoides sibogae, longevity, spawning season

\section{Introduction}

The jack-knife shrimp, Haliporoides sibogae (De Man) is widely distributed along the continental shelf and slope between the depths of 100 and $1,460 \mathrm{~m}$ in the Indo-West Pacific, with report from Madagascar, the South China Sea, the Malay Archipelago, Australia, New Zealand and Japan (Holthuis, 1980). This species is commercially important and since the late 1950's has been exploited in various areas, around Japan, including off Tokushima Prefecture, Suruga Bay in Shizuoka Prefecture, off Kagoshima Prefecture, off Miyazaki Prefecture and outside of the Kii Channel (Kuroiwa et al. 1957, Ohnishi 1976, Tokudome 1983, Higashi \& Tokudome 1986, Hashimoto \& Matsuzawa 1986, Ueta et al. 1988).

In Kagoshima Prefecture, the annual catch of jack-knife shrimps was stable at 350-500 tons until the early 1980's. However, the shrimp population in the fishing grounds to the west of Kagoshima decreased sharply in the mid 1980's through overfishing without appropriate stock management (Higashi 1988, Ohtomi \& Matsuoka 1998). Since then, studies on the reproduction and growth of this shrimp based on adults and a few juveniles, have been carried out to enable appropriate stock management in this fishery (Ohtomi \& Yamamoto 1997, Ohtomi \& Matsuoka 1998).

\footnotetext{
*Corresponding author: Jun Hashimoto; E-mail, junh@nagasaki-u.ac.jp
}

A population of $H$. sibogae is also widely distributed on the continental slope southwest of Nagasaki in the East China Sea between the depths of 300 and $500 \mathrm{~m}$, although $H$. sibogae is not utilized as a fisheries resource in Nagasaki (Kosuge \& Horikawa 1997). An appropriate utilization plan for this shrimp population as a fisheries resource is still being sought by the Nagasaki Prefectural Institute of Fisheries (Takata et al. 1981) and it is imperative that more detailed information on it's the biology, is accumulated for prospective utilization. From 2006 to 2009, a series of beam-trawl surveys by the T/S Nagasaki-Maru of Nagasaki University was conducted to obtain detailed biological information on the shrimp population on the continental slope in these waters. The present paper describes the maturation, spawning season, longevity, growth, relative growth and sex ratio of $H$. sibogae southwest of Nagasaki.

\section{Materials and Methods}

Shrimps were collected by beam trawl from the upper continental slope between the depths of 367 and $444 \mathrm{~m}$ in the area southwest of Nagasaki (Fig. 1). The beam width was $3 \mathrm{~m}$, and the sleds $0.8 \mathrm{~m}$ in height. The mesh sizes of the outer and inner nets were ca. $48 \mathrm{~mm}$ and ca. $4 \mathrm{~mm}$, respectively. The trawl was towed by the T/S Nagasaki-Maru for $30 \mathrm{~min}$ (from bottom contact to leaving the bottom) at a 


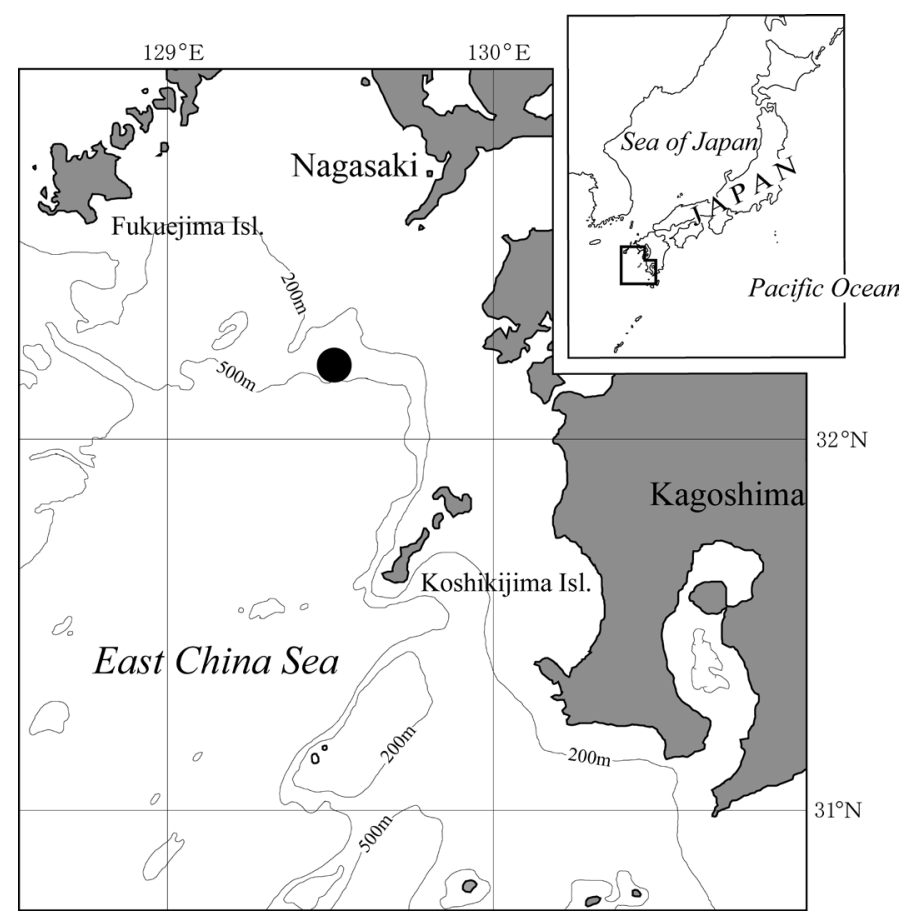

Fig. 1. Map showing the sampling site

of Haliporoides sibogae southwest of Nagasaki with deep-sea bathymetry overlaid.

Table 1. List of samples collected by a beam trawl to the southwest of Nagasaki.

\begin{tabular}{|c|c|c|c|c|c|c|c|c|}
\hline \multirow{3}{*}{ Sampling date } & \multirow{3}{*}{ Depth (m) } & \multirow{2}{*}{\multicolumn{2}{|c|}{ Reached Bottom }} & \multirow{2}{*}{\multicolumn{2}{|c|}{ Left Bottom }} & \multicolumn{3}{|c|}{ Number of individuals } \\
\hline & & & & & & \multicolumn{2}{|c|}{$\mathrm{CL}>11 \mathrm{~mm}$} & \multirow{2}{*}{$\frac{\mathrm{CL}<11 \mathrm{~mm}}{\text { Juvenile }}$} \\
\hline & & Latitude & Longitude & Latitude & Longitude & Female & Male & \\
\hline 12 May 2006 & $415-393$ & $32^{\circ} 15.11^{\prime} \mathrm{N}$ & $129^{\circ} 28.55^{\prime} \mathrm{E}$ & $32^{\circ} 14.65^{\prime} \mathrm{N}$ & $129^{\circ} 27.08^{\prime} \mathrm{E}$ & 396 & 349 & 0 \\
\hline 26 May 2006 & $409-420$ & $32^{\circ} 14.69^{\prime} \mathrm{N}$ & $129^{\circ} 28.09^{\prime} \mathrm{E}$ & $32^{\circ} 15.36^{\prime} \mathrm{N}$ & $129^{\circ} 29.43^{\prime} \mathrm{E}$ & 226 & 253 & 1 \\
\hline 30 June 2006 & $439-444$ & $32^{\circ} 13.28^{\prime} \mathrm{N}$ & $129^{\circ} 28.59^{\prime} \mathrm{E}$ & $32^{\circ} 13.56^{\prime} \mathrm{N}$ & $129^{\circ} 30.40^{\prime} \mathrm{E}$ & 90 & 78 & 0 \\
\hline 15 July 2006 & $429-432$ & $32^{\circ} 13.35^{\prime} \mathrm{N}$ & $129^{\circ} 27.45^{\prime} \mathrm{E}$ & $32^{\circ} 14.05^{\prime} \mathrm{N}$ & $129^{\circ} 28.94^{\prime} \mathrm{E}$ & 94 & 83 & 1 \\
\hline 02 Aug. 2006 & $367-383$ & $32^{\circ} 14.28^{\prime} \mathrm{N}$ & $129^{\circ} 31.73^{\prime} \mathrm{E}$ & $32^{\circ} 15.33^{\prime} \mathrm{N}$ & $129^{\circ} 31.08^{\prime} \mathrm{E}$ & 35 & 33 & 0 \\
\hline 28 Sept. 2006 & $418-418$ & $32^{\circ} 12.94^{\prime} \mathrm{N}$ & $129^{\circ} 26.17^{\prime} \mathrm{E}$ & $32^{\circ} 13.67^{\prime} \mathrm{N}$ & $129^{\circ} 27.28^{\prime} \mathrm{E}$ & 72 & 47 & 0 \\
\hline 28 Oct. 2006 & $414-419$ & $32^{\circ} 15.02^{\prime} \mathrm{N}$ & $129^{\circ} 30.16^{\prime} \mathrm{E}$ & $32^{\circ} 14.63^{\prime} \mathrm{N}$ & $129^{\circ} 28.69^{\prime} \mathrm{E}$ & 102 & 67 & 4 \\
\hline 15 Nov. 2006 & $370-378$ & $32^{\circ} 14.40^{\prime} \mathrm{N}$ & $129^{\circ} 26.80^{\prime} \mathrm{E}$ & $32^{\circ} 15.46^{\prime} \mathrm{N}$ & $129^{\circ} 28.05^{\prime} \mathrm{E}$ & 194 & 175 & 44 \\
\hline 13 Dec. 2006 & $407-400$ & $32^{\circ} 15.61^{\prime} \mathrm{N}$ & $129^{\circ} 28.91^{\prime} \mathrm{E}$ & $32^{\circ} 14.80^{\prime} \mathrm{N}$ & $129^{\circ} 27.94^{\prime} \mathrm{E}$ & 208 & 236 & 76 \\
\hline 11 Jan. 2007 & $414-419$ & $32^{\circ} 14.87^{\prime} \mathrm{N}$ & $129^{\circ} 28.74^{\prime} \mathrm{E}$ & $32^{\circ} 13.72^{\prime} \mathrm{N}$ & $129^{\circ} 27.48^{\prime} \mathrm{E}$ & 201 & 204 & 11 \\
\hline 28 Feb. 2007 & $378-377$ & $32^{\circ} 13.76^{\prime} \mathrm{N}$ & $129^{\circ} 26.25^{\prime} \mathrm{E}$ & $32^{\circ} 14.64^{\prime} \mathrm{N}$ & $129^{\circ} 27.20^{\prime} \mathrm{E}$ & 101 & 113 & 1 \\
\hline 20 Mar. 2007 & $413-407$ & $32^{\circ} 13.89^{\prime} \mathrm{N}$ & $129^{\circ} 14.72^{\prime} \mathrm{E}$ & $32^{\circ} 14.74^{\prime} \mathrm{N}$ & $129^{\circ} 28.70^{\prime} \mathrm{E}$ & 89 & 118 & 0 \\
\hline 07 Mar. 2009* & $404-399$ & $32^{\circ} 15.75^{\prime} \mathrm{N}$ & $129^{\circ} 29.54^{\prime} \mathrm{E}$ & $32^{\circ} 14.66^{\prime} \mathrm{N}$ & $129^{\circ} 28.09^{\prime} \mathrm{E}$ & 31 & - & - \\
\hline
\end{tabular}

* for histological observation.

speed of ca. 2.5-3.0 knots. Monthly samplings were conducted between May 2006 and March 2007, and a total of 3,702 specimens were collected. In addition to these samples, 31 shrimps were collected in March 2009 to examine the state of ovarian maturation (Table 1). CTD observations (SeaBird Co. Ltd. plus 9) were conducted immediately before and after beam trawl sampling. The temperature and salinity ranges of the habitat were $8.48-10.70^{\circ} \mathrm{C}$ and 34.353-34.398, respectively.

Samples were stored in $10 \%$ buffered formalin or in a deep-freezer $\left(-30^{\circ} \mathrm{C}\right)$. Body length (BL: length between posterior margin of orbit and posterior edge of telson) and carapace length (CL: length between posterior margin of orbit and posterodorsal edge of carapace) were measured with calipers accurate to $0.05 \mathrm{~mm}$, and body weight (BW) and gonad weight (females) were weighed using an electric 
balance accurate to $0.01 \mathrm{~g}$. Sex was determined by the presence of a petasma in males. The gonadosomatic index (GSI) was calculated as $100 \mathrm{GW} / \mathrm{BW}$.

Some samples for histological observation were fixed with Davidson's fluid. Small pieces of the ventral lobe were cut out from the ovary of the fixed samples, dehydrated through an ethanol series and embedded in paraffin. Sections of $5 \mu \mathrm{m}$ thickness were double stained with Mayer's hematoxylin and eosin.

Frequency distributions of carapace length (CL) were obtained for each sex at $5 \mathrm{~mm}$ intervals for each sample, and estimated mean values from each normal distribution were applied to compute growth equations for males and females. Each parameter was obtained by the least squares method.

CL growth patterns were examined using two growth equations (von Bertalanffy 1938; Pauly and Gaschüktz 1979) derived from the CL means estimated for component normal distribution at ages on the sampling dates used following the methods of Ohtomi and Matsuoka (1998). Akaike's Information Criterion (Akaike 1973) was used to compare fitting of the growth curves. The sex ratios for each size and each age group, and the relationships among $\mathrm{CL}, \mathrm{BL}$ and $\mathrm{BW}$ for males and females were also examined.

\section{Result and Discussion}

\section{Gonadosomatic index with ovarian maturation}

Histological observations were made on 31 females of H. sibogae (CL: $37.6-30.5 \mathrm{~mm}$ ), fixed with Davidson's fluid. Their GSIs varied between 0.78 and $11.54 \%$. Ovaries were classified into four developmental stages: (1) undeveloped (oocytes in previtellogenesis; Fig. 2-I); (2) early-ripe (yolk granules staining with eosin are recognizable in the cytoplasm; Fig. 2-II); (3) nearly-ripe (cortical crypts in the peripheral region of the oocytes; Fig. 2-III); and (4) ripe (yolk granules throughout the cytoplasm in oocytes and germinal vesicle breakdown occurring; Fig. 2-IV).

Haliporoides sibogae has an asynchronous type of ovary that contains oocytes at various developmental stages (Ohomi \& Yamamoto 1997). Therefore, the ovarian maturity stage of this shrimp depends on the developmental stage of the most advanced oocytes in the ovary. There was no significant correlation between GSI and CL in each ovarian developmental stage according to a simple regression analysis (undeveloped, $\mathrm{p}=0.495$; early-ripe, $\mathrm{p}=0.378$; nearly-ripe, $p=0.180$; and ripe, $p=0.001$ ). Therefore, significant differences in GSI mean value were obtained among ovarian maturation stages (by the analysis of variance and the test for the mean with $95 \%$ confidence limits of the difference) similar to the findings of Ohtomi \& Yamamoto (1997). These results revealed a significant increase in GSI with ovarian maturation. Cortical crypts were observed in females at both nearly-ripe and ripe ovarian stages, so females with ovaries in these developmental stages were defined as mature females which would spawn within a few days. The percentage occurrence of females at each ovarian maturity stage by GSI class is shown in Fig. 3. Mature females of this shrimp population coincide with GSI values exceeding $8 \%$ (Fig. 3-III and IV), which was therefore subsequently as the criterion for female maturity.
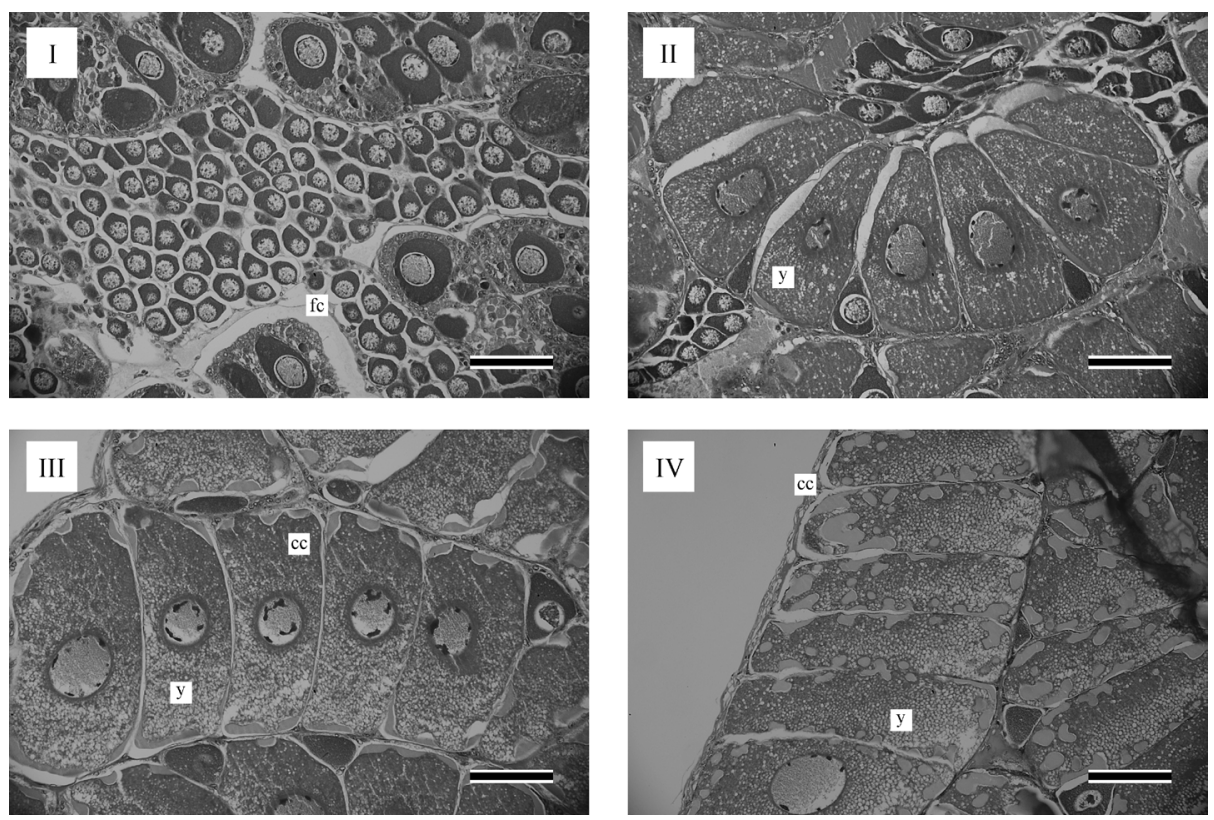

Fig. 2. Histological staging of ovarian development in Haliporoides sibogae. I; undeveloped stage, II; early-ripe stage, III; nearly-ripe stage, IV; ripe stage, fc; follicle, y; yolk granules, cc; cortical crypts. Scale bars $=100 \mu \mathrm{m}$. 


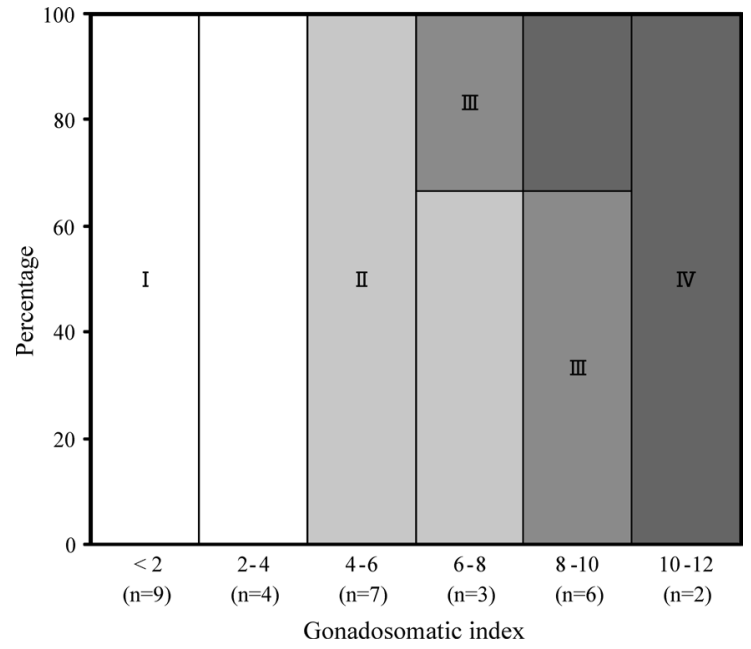

Fig. 3. Percentage occurrences of females of Haliporoides sibogae with each ovarian maturity stage by GSI class. I; undeveloped stage, II; early-ripe stage, III; nearly-ripe stage, IV; ripe stage.

\section{Spawning season}

The monthly relationship between GSI and CL was examined to clarify the season for mature females with a GSI exceeding $8 \%$, based on 1,808 females (CL $>11 \mathrm{~mm}$ ) collected between May 2006 and March 2007 (Fig. 4.). Earlyripe ovaries $(8 \%>\mathrm{GSI}>4 \%)$ appeared from the end of September to the end of October, undeveloped females $(4 \%>\mathrm{GSI})$ occurred all year round (Fig. 4$)$; ripe females (GSI $>8 \%$ ) were confirmed from the middle of November to the end of March; and mature females were found in increasing numbers in the middle of January and the end of February. This indicates that the spawning season of the H. sibogae population southwest of Nagasaki is November to March, with the main spawning season in January and February. Large mature females $(\mathrm{CL}>30 \mathrm{~mm})$, and small mature females $(C L<30 \mathrm{~mm})$, occurred only during the primary spawning season (Fig. 4). Baelde (1992) reported two separate spawning seasons (February-April and JulyAugust) for the east-Australian population of H. sibogae. However, the spawning season for the southwest of Nagasaki population appears to be only once a year from November to March, which is somewhat different from the west Kagoshima population reported by Ohtomi \& Yamamoto (1997).

\section{Longevity}

The monthly CL frequency distributions of $H$. sibogae males and females, using 3,564 individuals collected between May 2006 and March 2007, were analyzed to estimate longevity (Fig. 5). Two age group normal distributions are recognizable from May to November, and three normal distributions are evident from December to March. The normal distributions of the young age group for both males and females in December are from newly recruited individuals and are recognizable until March. This is an increase of one normal age group distribution compared with previous studies in Japanese waters (Ueta et al. 1988, Ohtomi \& Matsuoka 1998). The first recruitment season for both males and females of $H$. sibogae to the southwest of Nagasaki with mean CL size around $12.5 \mathrm{~mm}$ was in the beginning of winter (December), and the mortality period of shrimps with a mean CL size of about $33 \mathrm{~mm}$ is estimated to be in mid spring (around April). The longevity of both males and females of $H$. sibogae was estimated to be about 38 months on the basis of an arbitrary assignment of the 1st February to be when most mature females occurred (Fig. 4). This estimated longevity of the southwestern Nagasaki population is 7 to 13 months longer than that of populations to the west of Kagoshima (Ohtomi \& Matsuoka 1998) and outside the Kii Channel (Ueta et al. 1988). Apart from these male and female shrimps in Fig. 5, 138 individuals of juveniles ( $\mathrm{CL}<11 \mathrm{~mm}$; unknown sex) were collected between May 2006 and February 2007. The primary spawning season appears to start in November indicateing that the duration of incubation and/or planktonic phase of the shrimp population in the southwestern of Nagasaki is less than six months. This is two months shorter than that of the western Kagoshima population (Ohtomi \& Matsuoka 1998).

Jack-knife shrimps are distributed in Japanese waters from the continental shelf margin and continental slope between 200 and $500 \mathrm{~m}$, and the temperature range is approximately $9-14^{\circ} \mathrm{C}$ (Ueta et al. 1988). The linear distance between the sampling sites southwest of Nagasaki and to the west of Kagoshima is less than $80 \mathrm{~km}$. Although the temperature range and depth of both sampling sites were similar (approximately $9-10^{\circ} \mathrm{C}, 400 \mathrm{~m}$ depth), few juveniles were collected from the Kagoshima sampling site (Ohtomi \& Matsuoka 1998). Therefore there was one additional normal distribution of age group in the Kagoshima population recognized in the present study, compared with the two age groups previously reported. It is considered that the Kii Channel population (Ueta et al. 1988) is the same as that of the population west of Kagoshima. Differences in longevity of this shrimp from previous studies around Japanese waters (Ueta et al. 1988, Ohtomi \& Matsuoka 1998) may be caused by random sampling from fishing products and/or selectivity based on differing mesh size of the sampling gear.

\section{Growth}

To clarify the growth rate of this shrimp population southwest of Nagasaki, the mean values for each cohort obtained from the CL frequency distributions of both sexes were adapted for von Bertalanffy and Pauly and Gaschütz growth equations using the least squares method. Although detailed information on the earlylife history of this shrimp is unknown, assigning the starting date of the life history is essential to applying the growth equations. Therefore, the ages of individuals belonging to each cohort 


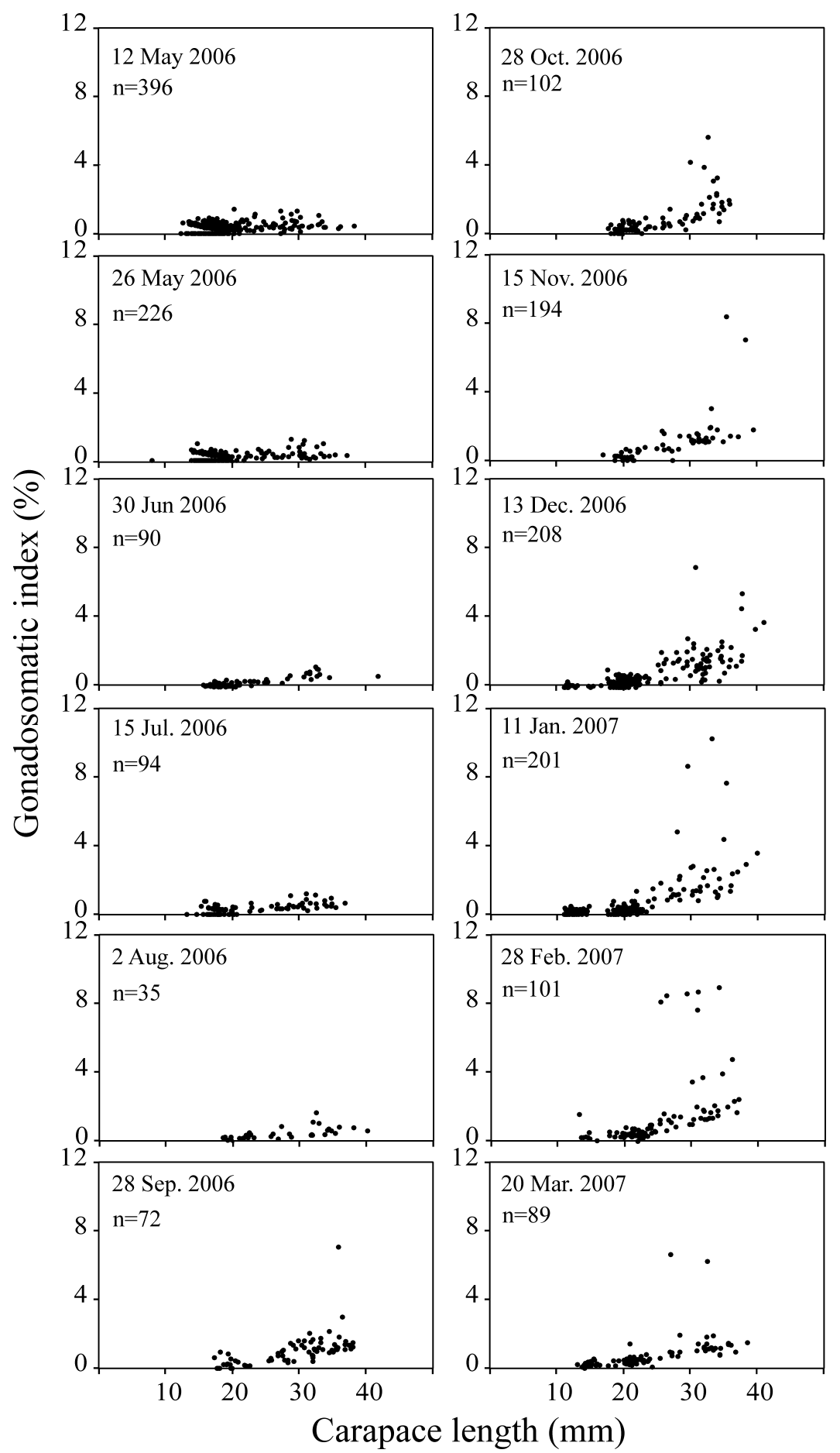

Fig. 4. Monthly trend in the relationship between the carapace length (CL) and gonadosomatic index (GSI) for female Haliporoides sibogae southwest of Nagasaki.

were estimated on the basis of arbitrary assignment of the 1st February as the birth date, which is the when most mature females occurred (Fig. 4). The AIC was calculated to compare adaptations in each growth curve. The growth equations and AIC obtained are as follows:
Pauly and Gaschütz (male)

$$
\begin{aligned}
\mathrm{Lt}= & 36.49[1-\exp \{-0.51(\mathrm{t} / 12-0.001) \\
& -(0.43 / 2 \pi) \sin (2 \pi(\mathrm{t} / 12-0.11))\}] \mathrm{AIC}=85.94
\end{aligned}
$$

Pauly and Gaschütz (female)

$$
\begin{aligned}
\mathrm{Lt}= & 50.50[1-\exp \{-0.40(\mathrm{t} / 12-0.21) \\
& -(0.29 / 2 \pi) \sin (2 \pi(\mathrm{t} / 12-0.03))\}] \mathrm{AIC}=112.29
\end{aligned}
$$


Male

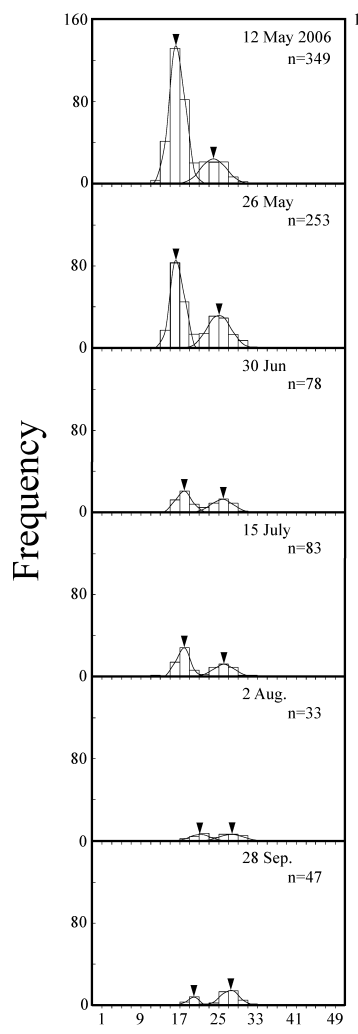

\section{0}

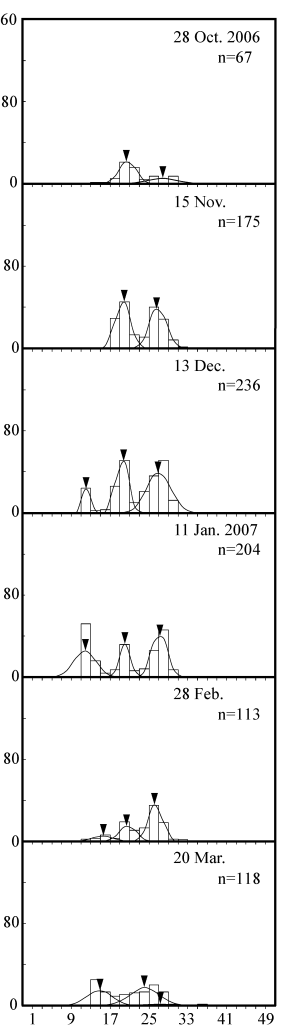

Female

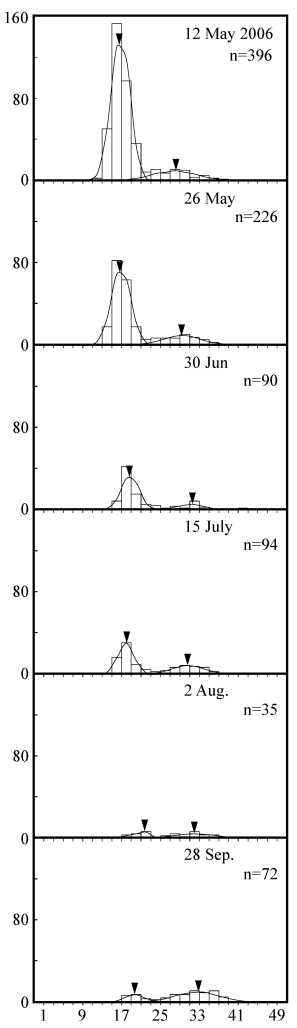

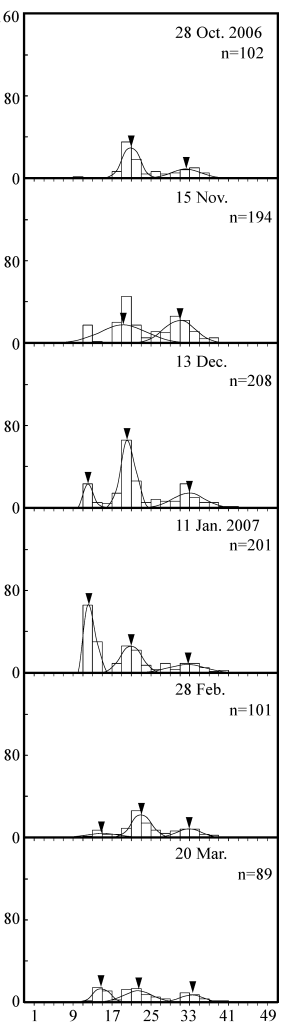

Carapace length $(\mathrm{mm})$

Fig. 5. Monthly trend in the carapace length (CL) frequency distributions of male and female Haliporoides sibogae southwest of Nagasaki. Thin line curves and black arrows indicate the estimated normal distributions of age groups and respective mean carapace length (CL).

von Bertalanffy (male)

$\mathrm{Lt}=33.30[1-\exp \{-0.05(\mathrm{t}-1.63)\}] \mathrm{AIC}=99.31$

von Bertalanffy (female)

$\mathrm{Lt}=46.10[1-\exp \{-0.04(\mathrm{t}-3.13)\}] \mathrm{AIC}=122.36$

The respective growth curves for both sexes according to von Bertalanffy and Pauly and Gaschütz are shown in Fig. 6. On the basis of AIC, the Pauly and Gaschütz growth equation is a better fit than the von Bertalanffy growth equation in both males and females. Difference in size between males and females was observed from about $15 \mathrm{~mm}$ CL (around 12 months postnatal), with a maximum $6 \mathrm{~mm}$ CL difference (about $14 \mathrm{~mm} \mathrm{BL}$ ) after around 24 months. The estimated asymptotic CL, growth coefficient and longevity for the population southwest of Nagasaki and another three local populations are shown in Table 2. The growth coefficient calculated in the present study is less than half that computed for the populations outside the Kii Channel (Ueta et al. 1988) and the west of Kagoshima (Ohtomi \& Matsuoka 1998), and nearly the same as the eastern Australian population (Baelde 1994), accompanied by prolonged longevity.

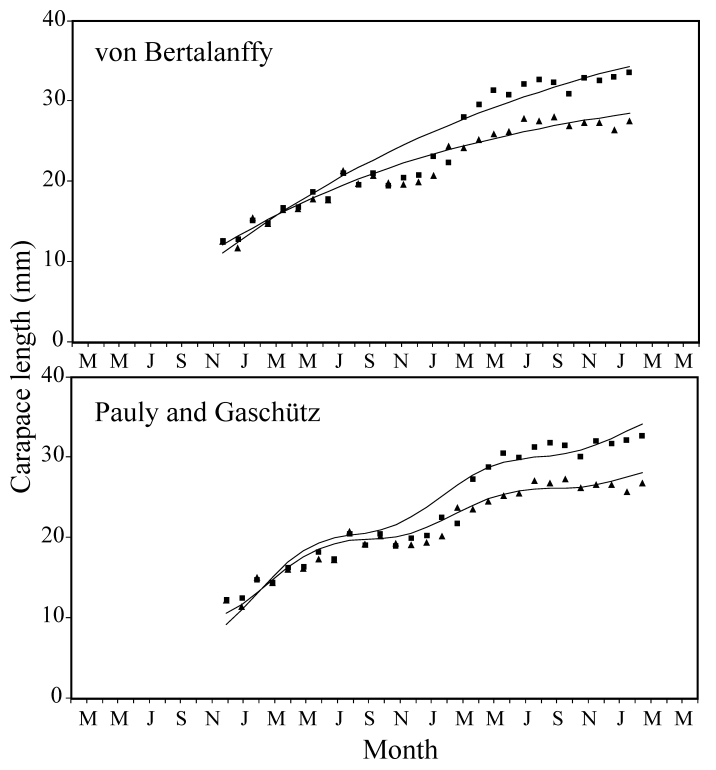

Fig. 6. Growth curves for male and female Haliporoides sibogae southwest of Nagasaki. Closed triangles (male) and closed squares (female) show the mean carapace length (CL) of age groups derived from Fig. 5. 
Table 2. Estimated asymptotic carapace length (CL), growth coefficient (per year), and longevity of four local populations of Haliporoides sibogae.

\begin{tabular}{|c|c|c|c|c|c|c|}
\hline \multirow{2}{*}{ Population } & \multicolumn{2}{|c|}{ Asymptotic carapace length $\left(\mathrm{L}_{\infty}\right)$} & \multicolumn{2}{|c|}{ Growth coefficient $(\mathrm{K})$} & \multirow{2}{*}{ Longevity } & \multirow{2}{*}{ Author(s) } \\
\hline & Male & Female & Male & Female & & \\
\hline $\begin{array}{l}\text { Eastern Australia } \\
\text { Japan }\end{array}$ & $33.5 \mathrm{~mm}$ & $48.3 \mathrm{~mm}$ & 0.490 & 0.370 & 48 months & Baelde (1994) \\
\hline Kii Channel & $32.5 \mathrm{~mm}$ & $39.0 \mathrm{~mm}$ & 0.922 & 0.823 & 25 months & Ueta et al. (1988) \\
\hline west of Kagoshima & $30.8^{*} \mathrm{~mm}$ & $39.6^{*} \mathrm{~mm}$ & 1.740 & 1.275 & 30 months & Ohtomi \& Matsuoka (1998) \\
\hline southwest of Nagasaki & $36.5 \mathrm{~mm}$ & $50.5 \mathrm{~mm}$ & 0.510 & 0.400 & 38 months & Present study \\
\hline
\end{tabular}

* corrected from BL to CL using the equations representing CL-BL relationship (present study).

\section{Sex ratio (\% females)}

The sex ratio for $H$. sibogae to the southwest of Nagasaki was obtained based on 3,564 specimens and was $50 \%$ for the total population, but varying markedly with CL. The sex ratio for juveniles $(\mathrm{CL}<23 \mathrm{~mm})$ also was around $50 \%$, but for young shrimps $(24 \mathrm{~mm}<\mathrm{CL}<28 \mathrm{~mm}$ ) was significantly different at less than $26 \%$. The ratio for older shrimps ( $29 \mathrm{~mm}<\mathrm{CL}<31 \mathrm{~mm}$ ) reverted to around $50 \%$, and for the oldest shrimps (CL>32-33 mm) was over 95\%. A similar phenomenon (extremely high sex ratio for the oldest members) has been reported for the H. sibogae population outside of the Kii Channel and in eastern Australia (Ueda et al. 1988, Baelde 1992). In the same manner as in those shrimp populations, males to the southwest of Nagasaki also probably have a short generation time compared with females.

A decrease in the sex ratio was observed for each age group of this shrimp population: higher between 10 and 24 months (except for the 13 month age group collected in March), while the number of males exceeded females (i.e., females $<50 \%$ ) between 25 and 28 months of age in March to June. There were slightly more females than males at age 29-33 months, from July to November, while the percentage declined below 50\% again at age 34-36 months from December to February. The female percentage was extremely high for the 37 month age group (Table 3). In the present study, shrimp samples were collected at a fixed point on the upper continental slope southwest of Nagasaki between the depths of 367 and $444 \mathrm{~m}$ and the spawning season was estimated to be from November to March. The observed decrease in sex ratio might be due to migration of females of $H$. sibogae to different depths or geographical areas in and around the spawning season.

\section{Relative growth}

Regression equations were obtained to examine the correlations among BL, BW and CL. All regressions were significant statistically, and significant differences between males and females were also confirmed by analysis of covariance for each regression (Table 4). The CL/BL ratio in the population southwest of Nagasaki population was larger for males than for females, a result is similar to that
Table 3. Sex ratio of each age group of Haliporoides sibogae to the southwest of Nagasaki.

\begin{tabular}{|c|c|c|c|c|}
\hline \multirow{2}{*}{$\begin{array}{l}\text { sampling } \\
\text { date }\end{array}$} & \multirow{2}{*}{$\begin{array}{l}\text { age group } \\
\text { (month) }\end{array}$} & \multicolumn{2}{|c|}{ mean CL (mm) } & \multirow{2}{*}{$\begin{array}{c}\text { sex ratio } \\
(\% \text { female })\end{array}$} \\
\hline & & females & males & \\
\hline 13-Dec. & 10 & 12.6 & 12.5 & 51 \\
\hline 11-Jan. & 11 & 12.8 & 11.7 & 56 \\
\hline 28-Feb. & 12 & 15.2 & 15.4 & 53 \\
\hline 20-Mar. & 13 & 14.8 & 14.7 & 37 \\
\hline 12-May & 14 & 16.7 & 16.4 & 56 \\
\hline 26-May & 15 & 16.8 & 16.5 & 55 \\
\hline 30-June & 16 & 18.7 & 17.7 & 64 \\
\hline 15-July & 17 & 17.8 & 17.6 & 55 \\
\hline 2-Aug. & 18 & 21.0 & 21.2 & 48 \\
\hline 28-Sep. & 19 & 19.6 & 19.6 & 59 \\
\hline 28-Oct. & 20 & 21.0 & 20.6 & 59 \\
\hline 15-Nov. & 21 & 19.4 & 19.7 & 54 \\
\hline 13-Dec. & 22 & 20.4 & 19.5 & 59 \\
\hline 11-Jan. & 23 & 20.8 & 19.8 & 61 \\
\hline 28-Feb. & 24 & 23.1 & 20.6 & 64 \\
\hline 20-Mar. & 25 & 22.3 & 24.2 & 38 \\
\hline 12-May & 26 & 27.9 & 24.0 & 41 \\
\hline 26-May & 27 & 29.4 & 25.0 & 29 \\
\hline 30-June & 28 & 31.2 & 25.7 & 31 \\
\hline 15-July & 29 & 30.7 & 26.0 & 50 \\
\hline 2-Aug. & 30 & 32.0 & 27.6 & 53 \\
\hline 28-Sep. & 31 & 32.5 & 27.3 & 61 \\
\hline 28-Oct. & 32 & 32.2 & 27.8 & 62 \\
\hline 15-Nov. & 33 & 30.8 & 26.7 & 51 \\
\hline 13-Dec. & 34 & 32.7 & 27.1 & 32 \\
\hline 11-Jan. & 35 & 32.4 & 27.1 & 30 \\
\hline 28-Feb. & 36 & 32.9 & 26.2 & 30 \\
\hline 20-Mar. & 37 & 33.4 & 27.3 & 78 \\
\hline
\end{tabular}

for the population outside the Kii Channel (Ueta et al. 1988). The growth of each measured part for H. sibogae was compared by the obtained regression equations $\left(\mathrm{Y}=\mathrm{aX} \mathrm{X}^{\mathrm{b}}\right)$. Generally, if the coefficient (b) of such regressions is within the range from 0.9 to 1.1, the growth rate of one part of a crustacean can be considered to equal that of 
Table 4. Regression equations for the relative growth between several body parts in Haliporoides sibogae.

\begin{tabular}{|c|c|c|c|c|c|c|}
\hline Sex & $\mathrm{X}$ & $\mathrm{Y}$ & Regression equation & $\mathrm{n}$ & $\mathrm{R}^{2}$ & $\mathrm{p}$ \\
\hline \multirow[t]{4}{*}{ Male } & \multirow[t]{2}{*}{ Body length (mm) } & Body weight (g) & $Y=-11.884 X^{3.113}$ & \multirow[t]{4}{*}{1,756} & 0.985 & $<0.00001$ \\
\hline & & Carapace length (mm) & $\mathrm{Y}=-1.433 \mathrm{X}^{1.022}$ & & 0.976 & $<0.00001$ \\
\hline & \multirow[t]{2}{*}{ Carapace length $(\mathrm{mm})$} & Body length (mm) & $\mathrm{Y}=1.472 \mathrm{X}^{0.955}$ & & 0.976 & $<0.00001$ \\
\hline & & Body weight (g) & $Y=-7.361 X^{2.994}$ & & 0.974 & $<0.00001$ \\
\hline \multirow[t]{4}{*}{ Female } & \multirow[t]{2}{*}{ Body length (mm) } & Body weight (g) & $Y=-11.936 X^{3.130}$ & \multirow[t]{4}{*}{1,808} & 0.985 & $<0.00001$ \\
\hline & & Carapace length (mm) & $Y=-1.755 X^{1.103}$ & & 0.982 & $<0.00001$ \\
\hline & \multirow[t]{2}{*}{ Carapace length $(\mathrm{mm})$} & Body length (mm) & $Y=1.642 X^{0.890}$ & & 0.982 & $<0.00001$ \\
\hline & & Body weight (g) & $Y=-6.848 X^{2.802}$ & & 0.979 & $<0.00001$ \\
\hline
\end{tabular}
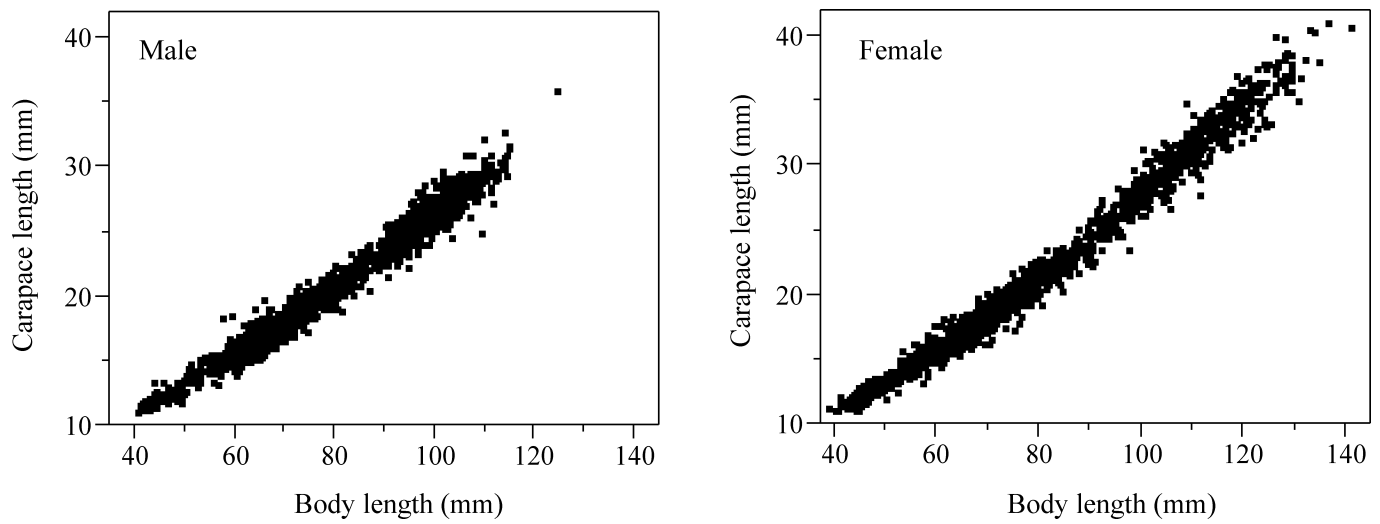

Fig. 7. Relationships between natural logarithm of carapace length (CL) and natural logarithm of body length (CL) for male and female Haliporoides sibogae southwest of Nagasaki.

another part (Kuris \& Carlton 1997, Lovett \& Felder 1989). In the present study, coefficient (b) of the BL-CL and CL-BL equations for females is beyond that range (Table 4 ), so the body and carapace growth rates in females are considered to be allometric. However, the inflection point is only an estimate in the BL-CL regression equation for females because there are no obvious discontinuities in the curve. The inflection point is assumed to lie at a CL of 22-26 mm (Fig. 7), because the minimum CL of mature females was $25.7 \mathrm{~mm}$ (Fig. 4).

Following Ohtomi et al. (2004), the minimum value was calculated for the total of error sum of squares of two regression equations obtained for arbitrary parting point at intervals of $0.1 \mathrm{~mm}$. The best parting point of the regression equations was obtained at a CL of $25.0 \mathrm{~mm}$. The allometric growth of CL in females is considered to be a secondary sexual character of $H$. sibogae in the southwest of Nagasaki, because this CL $(25.0 \mathrm{~mm})$ is close to the minimum CL of mature females in this shrimp population (25.7 $\mathrm{mm})$.

\section{Acknowledgements}

We wish to thank Prof. Jun Ohtomi of Kagoshima University for his invaluable comments, and Emeritus Prof.
Kazuma Yoshikoshi of Nagasaki University for his earnest advice regarding microscopic observations. The captain and crews of the T/S Nagasaki-Maru are especially acknowledged for their support throughout the sampling period.

\section{References}

Akaike H (1973) Information theory and an extension of the maximum likelihood principle. (eds Petrov B N, Csaki F). The Second International Symposium on Information Theory. Akademiai Kiado, Budapest, 267-281.

Baelde P (1992) Reproductive biology of commercially exploited deep-water royal red prawns (Haliporoides sibogae, Solenoceridae) in south-east Australia. Mar Biol 113: 447-456.

Baelde P (1994) Growth, mortality and yield-per-recruit of deepwater royal red prawns (Haliporoides sibogae) off eastern Australia, using the length-based MULTIFAN method. Mar Biol 118: 617-625.

Hashimoto J, Matsuzawa S (1986) Distributional property of deep sea shrimps, Plesionica martia and Parahaliporus sibogae, in Hyuga Nada. JAMSTEC Deep-sea Res 2: 167-172. (in Japanese with English abstract)

Higashi T (1988) Research on management of fishery resources for Haliporoides sibogae. Bulletin of Kagoshima Pref Fish Stn, pp. 7. (in Japanese) 
Higashi T, Tokudome Y (1986) Deep sea shrimp-fishery in the waters of Satsunan sea region. Bull Jpn Soc of Fish Oceanogr 53: 281-285. (in Japanese)

Holthuis LB (1980) FAO Species Catalogue. Shrimps and Prawns of the World. An Annotated Catalogue of Species of Interest to Fisheries. FAO Fish Synopsis 125(1): pp. 271.

Kosuge T, Horikawa H (1997) Distribution and Size Composition of the Jack Knife Shrimp, Haliporoides sibogae on the Continental Slope in the East China Sea. Bull Seikai Reg Res Lab 75: 23-29.

Kuris, AM, Carlton JT (1977) Description of a new species, Crangon handi, and new genus, Lissocrangon, of crangonid shrimps (Crustacea: Cardidea) from the California coast, with notes on adaptation in body shape and coloration. Biol Bull 153: 540-549.

Kuroiwa M, Tonokai J, Uraguchi Y (1957) An examination of deep-sea trawl Fisheries. Fish Rep Tokushima Prefect Fish Exp Stn: 1-7. (in Japanese)

Lovett DL, Felder DL (1989) Application of regression techniques to studies of relative growth in crustaceans. J Crust Biol 17: 70-80.

Ohnishi K (1976) Studies on the Deep Sea Benthos off Shizuoka Prefecture-I. On the Distribution and Composition of Body Length in Suruga Bay. Bull Shizuoka Prefect Res Inst Fish 10: 23-46. (in Japanese)

Ohtomi J, Matsuoka T (1998) Reproduction and growth of Jackknife shrimp, Haliporoides sibogae, off south-western Kyu- shu, Japan. Fish Res 38: 271-281.

Ohtomi J, Yamamoto S (1997) Change in Gonadosomatic Index with Ovarian Maturation in Jack-knife Shrimp Haliporoides sibogae off South-western Kyushu, Japan. Fish Sci 63: 10441045.

Ohtomi J, Yokomura H, Hamano T (2004) Relative Growth of the Deep-water Stomatopod Crustacean Squilloides leptosquilla (Squillidae). Suisanzoshoku 52(1): 51-55. (in Japanese with English abstract)

Pauly D, Gaschütz G (1979) A Simple Method for Fitting Oscillating Length Growth Data, with a Program for Pocket Calculators. ICES CM 1979/G. 24. Demersal Fish Committee, 26 pp.

Takata J, Tokunaga T, Machida S, Tashiro M (1981) Distribution of a Penaeid, Perahaliporus sibogae in the adjacent Water of the Danjo Islands. Bull Nagasaki Prefect Inst Fish 7: 87-89. (in Japanese)

Tokudome Y (1983) Research of shrimps and demersal fishes resources in the coastal waters of Kagoshima Prefecture. Bull Kagoshima Prefect Fish Exp Stn: 7. (in Japanese)

Ueta Y, Jo Y, Nakamura K, Yuasa A (1988) Fisheries biology of Jack-knife shrimp Haliporoides sibogae in outer waters adjacent to Kii Channel. Fish Biol Oceanogr Nansei Reg Seas, Japan (Nansei gaikai no shigen kaiyo kenkyu) 4: 41-48. (in Japanese)

von Bertalanffy L (1938) A quantitative theory of organic growth (Inquiries on growth laws II). Human Biol 10: 181-213. 